\title{
Diasporic Experience in the Poetry of Meena Alexander
}

\author{
Dr. Shiva Sharma \\ Dr. A.B. Pandey \\ Assistant Professor of English \\ Govt. Thakur Ranmat Singh \\ P.G. College and Research Centre, Rewa(M.P.), India \\ Professor, Dept of English \\ Govt. College Raipur Karchuliyan \\ Rewa(M.P.), India
}

\begin{abstract}
On the literary map of Indian women writings, Meena Alexander appears to be leading woman poetess. Her poetry and trend setting novels and carefully constructed other literary articles have earned her literary fame of a serious and skillful author of the world in our modern age. In Indian writing she has established herself for her remarkable contribution to the development of art and ethos of novel writing techniques. Her poems create the cloned effects on our mind and heart for the varying Indian social values and present the microcosmic study of man-women relationship in the changed atmosphere of the modern times. Besides other things her poems deals with mostly, the urban city life in contact with nature and the socio-psycho attitudes of human mind caught in the crucible of tradition and change.
\end{abstract}

Keywords: Alienation and identity, separation and loneliness, tradition and change, diaspora and displacement.

Meena Alexander is one of the most brilliant and subtle writer who has described the meeting of Eastern and Western culture. She achieved the cohesive design of content and form in her psychological poems and novels and brings a thought provoking harmony over different streams of feeling and sensibility found in the different settings of human society. In her poems, we find a fine match between 'what is life?' and how it has to be lived? With natural make up among her poems, she commands a rich galaxy of characters both male and female, though articulates especially the feminine psyche from childhood to youth. She does not generate mute-characters, nor are their problems concerned with food, clothes and shelter. Instead, most of her protagonists are alienated from the world, from the society, from families and even from their own selves because they are not common people but the individuals made to stand against the general current of life and who fight and struggle against it to get the aspired world.

An article entitled Diaspora mean expatriate, immigrant. The term diaspora was firstly recorded in 1876 referring to refugees of the Irish feminine and it is widely assimilated in 1950s.

1. Diaspora carries a sense of dislocation, displacement and find itself separated from their original roots.

2. According to Homi Bhabha diaspora is "gathering of exile, emigrants and refugees in foreign culture and foreign land. Gathering of the past in ritual and revivals and that gathering in the present.

3. In some conceptual consideration by Fred W. Riggs defines Diaspora as communities whose member lives informally outside, a homeland while maintaining active contact with it.

The world informally excludes people having a formal status such as "soldiers, diplomats, missionaries, businessman, journalist, spies etc"(124) who are the agents of the state or non-state entities in the homeland. Toloyan who lunched a journal Diaspora stated, "we use Diaspora provisionally to indicate our belief that the term that once described Jewish, Greek, and American dispersion name shares meanings with a larger semantic domain that includes words like immigrant, expatriate, refugee, guest worker, exile community, overseas community, ethnic community"1. The above definitions point to the distinguish meaning of a fruitful discussion of diaspora.The poetess enunciates the familial bond with due emphasis and the apparent simplicity of expression as well

as social view makes the diasporic experience as an extended piece of wit. In her autobiography, 'Fault Lines' the familial bond is pronounced: 


\author{
"I skipped a whole ring \\ of life and made-up a \\ sensitive, cultured woman; \\ a woman who had a tradition \\ and a history-precisely what \\ I lacked... \\ a woman who had lived to \\ witness the birth pangs of nation,"2
}

The Indian Diaspora is the largest Diaspora in the world with its global presence and a history that dates back to the Indian civilization. The Indian Diaspora can be divided into three phases ancient, medieval and modern. The ancient Diaspora refers laborers, crafts men and traders who explored new lands for work, wealth and adventures. In medieval times, the British imperialism caused movement of the indentured laborers. In modern times, skilled, educated and intelligent Indians moved to the USA and other European countries for economic and professional reasons. They are decentred in the sense that they have moved away from their original centre nations, communities and affiliations. Gilroy writes, that 'the image of the ship living micro cultural, micro political system in motion effectively captures the trans-nationality and intercultural relations, the exchange of ideas and activism'(107). Diaspora is conditioned by the home shore they have left and the new shore they arrive at. Diasporic poets often face traumas of displacement and rootlessness. Nissim Ezekiel is a poet with cosmopolitan outlook and faith is synthesizing power of art. Bruce King remarks very aptly: A central concerns of Ezekiel's poems always has-been how, "in an era of scepticism and secularity one can live with a sense of grace, completeness, morality, truth and holiness." ${ }^{3}$

Meena Alexander is essentially a poet of countryside. And she reveals sincerity and intense concern for the plight of expatriate and immigrant who prefer to settle in another countries for some reason. The graphic description of river, clouds, birds, snow, starlight, seasons is full of detailed knowledge of country affairs. Here the thought becomes concrete and tangible:

$$
\begin{aligned}
& \text { "... With the death and duties } \\
& \text { And loss of cardamom and rubber estates, } \\
& \text { Our life changed. } \\
& \text { A Whole world shivered and cracked, } \\
& \text { and it filled my ears", }
\end{aligned}
$$

Alexander explores themes of memory, migration, Diaspora and displacement in her diasporic work. Her creative work lies at the intersection of post colonial ethnic American, and women's studies. Like her life, which has included multiple border crossings, her poems crosses traditional disciplinary boundaries and generates interdisciplinary dialogues. Poetry has been widely published as the New York Times Magazines. Meena is a genuine diasporic voice expressing her own life's diasporic experiences in her poetry uprooting and exile, alienation and identity, migrant memories and traumas, separation and loneliness all the way from India to Sudan and USA. She christened Mary Elizabeth but she has been called "Meena" since her birth and in her teenage she officially changed her name from Marry to Meena. She states, "I felt I had changed my name to what I already was, some truer self, stripped free of the colonial burden" in her autobiography Fault Lines (74). Representing her own multi-lingual nature.

\title{
"Fifteen years old in Khartoum,
}

I changed my name to Meena,

What everyone knew me as,

But just as important to me, The name under which

I started to write poems. ", 
A great amount of meaning is deliberately packed by the poetess into the poem. Writing further, she informs the readers that the plight of diaspora expressed in that little sphere, nothing less than a constable.

She writes:

$$
\begin{aligned}
& \text { "... After all, } \\
& \text { for such as we are the } \\
& \text { territories are not free. } \\
& \text { The world is not open, } \\
& \text { that endless space the emptiness } \\
& \text { of the American sublime to worse } \\
& \text { than a lie." }
\end{aligned}
$$

Here Alexander's lines marked by diasporic sensibility and diasporic experience which finds highly emotion, large expression in sensual, lyrical and metaphoric language. She has undergone multiple identities in multiple places. Meena turned to poetry at the age of eleven or twelve for her; it was the music of survival. She admits that there is an inner voice that speaks to her. Her poems express her own lived experience uprooting and exile, migrant memories, travelling to different places in India, Sudan and America. She has lived in different cities and towns like Allahabad, Tiruvella, Kozennceri, Pune, Khartoum, London, New York, Hyderabad, New Delhi Trivandrum etc. There she tries consciously to trace an Indian feminist tradition to locate and grand her own involvement with women's issues. In her collection The Shock of Arrival, Alexander embarks on precisely on the mythological image of Indian women like the long-suffering Sita of the Ramayana. She dwells on the issue of female sexuality in the national imaginary of India. In the fundamental myth of India, women have to bear the burden of female sexuality.

To conclude, her works marked by the sense of loss, the pair of exile and dislocation. Diaspora literature is the literature of the migrants, expressing their experiences and sense of displacement and loss of social constructs like nation, ethnicity, race, culture, language etc. their identity crisis, sense of alienation, nostalgia, loss and emptiness. They experience social isolation, cultural shock and stress. Therefore, in diasporic literature we come across the themes of emptiness, frustration, disillusionment, home sickness, racism and discrimination.

\section{WORK CITED}

Toloyan, Khachig. 1991 Commentory. In Dispora (Journal) 1(2): 225-228

Alexander, Meena. Fault Lines. New York: The Feminist Press, 2003. P.73-74.

King, Bruce. Three Indian Poets. OUP. India. p. 57-58

$>$ Alexander, Meena. Fault Lines. New York: The Feminist Press, 2003. P.73-74.

$>$ Ibid 2003, P.39

Ibid 2003, P.43 